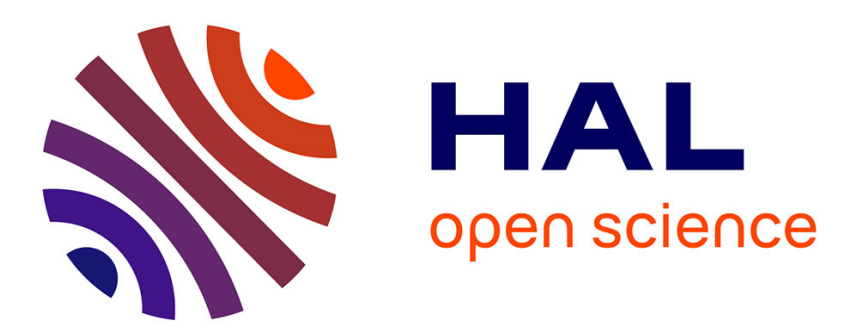

\title{
A counterexample on point inversion and projection for NURBS curve
}

Xiao-Diao Chen, Hua Su, Jun-Hai Yong, Jean-Claude Paul, Jia-Guang Sun

\section{To cite this version:}

Xiao-Diao Chen, Hua Su, Jun-Hai Yong, Jean-Claude Paul, Jia-Guang Sun. A counterexample on point inversion and projection for NURBS curve. Computer Aided Geometric Design, 2007, 24 (5), 10.1016/j.cagd.2007.03.008 . inria-00518368

\section{HAL Id: inria-00518368 \\ https://hal.inria.fr/inria-00518368}

Submitted on 17 Sep 2010

HAL is a multi-disciplinary open access archive for the deposit and dissemination of scientific research documents, whether they are published or not. The documents may come from teaching and research institutions in France or abroad, or from public or private research centers.
L'archive ouverte pluridisciplinaire $\mathbf{H A L}$, est destinée au dépôt et à la diffusion de documents scientifiques de niveau recherche, publiés ou non, émanant des établissements d'enseignement et de recherche français ou étrangers, des laboratoires publics ou privés. 


\title{
A counterexample on point inversion and projection for NURBS curve
}

\author{
Xiao-Diao Chen ${ }^{\mathrm{a}, \mathrm{b}, \mathrm{c}, *}$, Hua Su ${ }^{\mathrm{b}}$, Jun-Hai Yong ${ }^{\mathrm{b}}$, Jean-Claude Paul ${ }^{\mathrm{b}, \mathrm{c}}$, Jia-Guang Sun ${ }^{\mathrm{b}}$ \\ a Ningbo Institute of Technology, Zhejiang University, 315150, PR China \\ b School of Software, Tsinghua University, Beijing 100084, PR China \\ ${ }^{\mathrm{c}}$ CNRS, France
}

Received 10 July 2006; received in revised form 27 March 2007; accepted 30 March 2007

Available online 11 April 2007

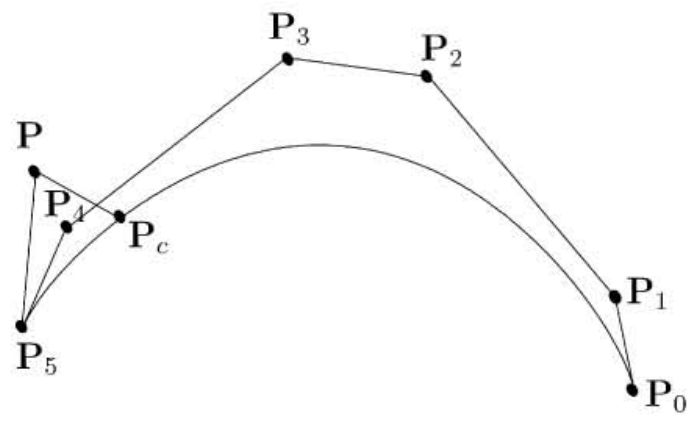

Fig. 1. A counterexample.

As shown in Fig. 1, the nearest point on a Bézier curve in $\mathbb{R}^{3}$ space with the control points $\left\{\mathbf{P}_{i}\right\}$ to the test point $\mathbf{P}$ is $\mathbf{P}_{c}$, while from the algorithm in (Ma and Hewitt, 2003), the nearest point is $\mathbf{P}_{5}$, which is an end point of the curve.

\section{Acknowledgements}

The research was supported by Chinese 973 Program (2004CB719400, 2004CB318000) and the National Science Foundation of China $(60403047,60533070,60473130)$. The third author was supported by the project sponsored by a Foundation for the Author of National Excellent Doctoral Dissertation of PR China (200342) and a Program for New Century Excellent Talents in University (NCET-04-0088).

\section{References}

Ma, Y.L., Hewitt, W.T., 2003. Point inversion and projection for NURBS curve and surface: control polygon approach. Computer Aided Geometric Design 20 (2), 79-99.

\footnotetext{
* Corresponding author at: Ningbo Institute of Technology, Zhejiang University, 315150, PR China. E-mail address: chenxd00@mails.tsinghua.edu.cn (X.-D. Chen).
} 